IZA DP No. 5529

Commuting Time and Labour Supply: A Causal Effect?

J. Ignacio Gimenez-Nadal José Alberto Molina

February 2011 


\title{
Commuting Time and Labour Supply: A Causal Effect?
}

\author{
J. Ignacio Gimenez-Nadal \\ University of Zaragoza \\ and CTUR (Oxford) \\ José Alberto Molina \\ University of Zaragoza \\ and IZA
}

\section{Discussion Paper No. 5529 \\ February 2011}

\author{
IZA \\ P.O. Box 7240 \\ 53072 Bonn \\ Germany \\ Phone: +49-228-3894-0 \\ Fax: +49-228-3894-180 \\ E-mail: iza@iza.org
}

\begin{abstract}
Any opinions expressed here are those of the author(s) and not those of IZA. Research published in this series may include views on policy, but the institute itself takes no institutional policy positions.

The Institute for the Study of Labor (IZA) in Bonn is a local and virtual international research center and a place of communication between science, politics and business. IZA is an independent nonprofit organization supported by Deutsche Post Foundation. The center is associated with the University of Bonn and offers a stimulating research environment through its international network, workshops and conferences, data service, project support, research visits and doctoral program. IZA engages in (i) original and internationally competitive research in all fields of labor economics, (ii) development of policy concepts, and (iii) dissemination of research results and concepts to the interested public.
\end{abstract}

IZA Discussion Papers often represent preliminary work and are circulated to encourage discussion. Citation of such a paper should account for its provisional character. A revised version may be available directly from the author. 
IZA Discussion Paper No. 5529

February 2011

\section{ABSTRACT}

\section{Commuting Time and Labour Supply: A Causal Effect?*}

We analyze the causal effect of the length of the worker's commute on worker's productivity, by examining whether commuting time has any effect on worker's labour market supply. Using the Spanish Time Use Survey 2002-03, our GMM/IV estimation yields a positive causal impact of commuting time on the time devoted to the labour market, with one hour of commuting increasing the time devoted to the labour market by 35 minutes in a working day. Our results shed light on the relationship between commuting and workers behaviour, since daily labour supply should be considered in theoretical models to provide a comprehensive view of commuter behaviour.

JEL Classification: R23, J22, J24

Keywords: commuting, labour supply, productivity, causality, Time Use Survey

Corresponding author:

Jose Ignacio Gimenez Nadal

Department of Economic Analysis

University of Zaragoza

Gran Via 2, planta 3. C.P.

50005 Zaragoza

Spain

E-mail: ngimenez@unizar.es

\footnotetext{
* We are grateful for the financial support provided by the Spanish Ministry of Education and Science (Project ECO2008-01297).
} 


\section{INTRODUCTION}

There are several reasons why the effect of commuting costs on labour market supply is of interest to economists (for a review, see Gibbons and Machin, 2006). For instance, policy makers may want to know whether congestion, as well as publicly-provided transport infrastructure, affects the decision of individuals with regard to how much time they spend on work (Hymel, 2009). Also, as suggested by Black et al. (2008), it may help to know whether significant increases in female labour supply are due to the reduction in commuting costs, resulting from improvements in transportation technology, or is it only a consequence of the increase of the educational level of women in recent decades. It may also concern employers, as there are many claims that workers with long commuting distances are more often absent and arrive late for work, affecting worker's productivity.

This paper examines the causal effect of commuting time on labour supply patterns, with a focus on daily labour supply defined as the number of hours worked during the day of interview. Many economists consider that higher commuting costs decrease labour supply (e.g. Bovenberg and Goulder, 1996; Mayeres and Proost, 2001; Parry and Bento, 2001), although other models allow for the possibility that commuting time has a positive effect on labour supply (Cogan, 1981; Parry and Bento, 2001; Black et al., 2008). There are divergent theoretical views on how to model the relationship between commuting costs and labour supply, and while some studies assume that the number of workdays is fixed and the number of work hours per day is freely chosen (e.g., Cogan, 1981), other studies make the opposite assumption (e.g., Parry and Bento, 2001).

Prior research done by Gutiérrez-i-Puigarnau and van Ommeren $(2010,2011)$ directly analyses the relationship between commuting distance and labour market behaviour. Gutiérrez-i-Puigarnau and van Ommeren (2010) find that in Germany, distance has a slight positive effect on daily and weekly labour supply, but no effect on the number of workdays, and that the effect is stronger (although still small) for females. Gutiérrez-iPuigarnau and van Ommeren (2011) find that in Germany, commuting distance induces absenteeism with an elasticity of about 0.07 to 0.09 , and thus absenteeism would be $15 \%$ to $20 \%$ less if all workers had a negligible commute. We complement such previous analysis by analyzing the causal relationship between commuting time and labour market hours. To the best of our knowledge, no other studies have directly 
analyzed this relationship between commuting time (costs) and labour market behaviour, especially in the field of labour economics.

Using the Spanish Time Use Survey (STUS) 2002-2003, we analyze the causal relationship between commuting time and labour market hours. Cogan (1981) establishes that when fixed costs of employment are present (the main example is commuting), the period of time over which the fixed costs are incurred determines the ideal modelling choice of the period of time of labour supply. That is to say, if fixed costs are per day, such as commuting costs, and these daily costs are important, then the appropriate measure of labour supply is daily labour supply. The STUS is a perfect dataset for this issue, since it allows us to measure the time devoted to both commuting and labour market during the same day, providing information on daily commuting time and on daily market hours. One of the main issues we are concerned with is that commuting time may be endogenous with respect to labour supply (i.e., the longer the commuting time, the shorter the time left for work) and, in consequence, we use GMM/IV models, despite previous literature emphasizing that it is not easy to find valid instruments for commuting distance (e.g., Manning, 2003; Gubits, 2004). We find a positive causal impact of commuting time on the time devoted to the labour market, with one hour of commuting increasing the time devoted to the labour market by 35 minutes in a working day.

By focusing on the relationship between the time devoted to both commuting and labour market hours during a working day, we shed light on how to model the relationship between commuting costs and labour supply. A common assumption in the urban economic literature is that private costs of commuting are fully borne by the worker and do not affect the worker's productivity. However, urban efficiency wage theories allow that worker's work effort is a function of the length of the commute (e.g., Zenou (2002) assumes that workers involuntarily provide less work effort due to larger commutes, while Ross and Zenou (2008) demonstrate that if shirking and leisure time are substitutes in the worker's utility function, then one may expect a positive effect of commuting on shirking). We argue that not only weekly labour supply but also daily labour supply should be considered in theoretical models in order to give a comprehensive view of commuter behaviour.

The remainder of the paper is organized as follows. Section 2 describes the data used in the paper. Section 3 describes the empirical strategy used to overcome the problem of 
endogeneity between commuting time and labour market hours. Section 4 presents the main results, and Section 5 sets out the main conclusions.

\section{DATA: THE SPANISH TIME USE SURVEY 2002-03}

The data used for the empirical analysis is drawn from the 2002-3 STUS, part of the Harmonized European Time Use Surveys (HETUS) launched by EUROSTAT, the statistical office of the European Union. It consists of a representative sample of 20,603 households and contains information on daily activities, gathered by means of the completion of a personal diary and household and individual questionnaires. The sample is evenly distributed over the year and the week in order to accurately represent timeuse patterns during all days of the week.

The survey includes an activities diary, which all members of the household aged 10 and older complete on a selected day (the same day for all members of the household). An extensive literature confirms the reliability and validity of diary data and their superiority over other time-use surveys based on stylized questions, asking respondents to estimate time spent in activities on a 'typical day' (e.g., Juster and Stafford 1991, Robinson and Godbey 1997). The diaries' time frame is twenty-four consecutive hours (from 6:00 a.m. until 6:00 a.m. the following day) and is divided into ten-minute intervals. In each of the intervals, the respondent records a main activity.

Activities are coded according to a harmonized list established by EUROSTAT and are grouped into ten major categories: personal care, paid work, studies, household and family, volunteer work and meetings, social life and recreation, sports and open-air activities, hobbies and games, means of communication, and non-specified travel and use of time. ${ }^{1}$

Time Use Variables. We consider the time reported to market work/commuting as primary activities in the day of the interview. Thus, Market Work is defined as the sum of the time devoted to "paid work - main job (not at home)", "paid work at home”, "second or other job not at home”, "travel as a part of work" and “other time at workplace”. Commuting is defined as the time devoted to "travel to or from work". Both activities are measured in hours per day. What differentiates "travel as a part of work"

1 A full description of activities can be found in the Spanish Statistical Office, http://www.ine.es/prodyser/micro_emptiem.htm. 
from "travel to or from work" is the diarist's perception, in the sense that it is the diarist who codes the activity as being part of work, or as being commuting time. For instance, in cases where the diarist works as a delivery man/woman, it may be the case that he/she needs time to go from home to the place where the delivery van is located (commuting), so that such travelling time is not part of the job.

Sample. For the sake of comparison with previous studies, and to minimize the role of time allocation decisions that have a strong inter-temporal component over the life cycle, such as education and retirement, we restrict our samples to non-retired/nonstudent individuals between the ages of 24 and 65 (inclusive). Our results can thus be interpreted as being 'per working-age adult' (Aguiar and Hurst 2007). Additionally, we exclude 'low quality' diaries from the analysis, following the Multinational Time Use Study (MTUS) coding procedures. ${ }^{2}$

We also restrict the sample to include only respondents who performed at least one hour of market work during the day of the interview, since there may be cases where respondents are having a day off, but they go to their work place for some non-work purpose. In this situation, we cannot consider such a day as a working day and, for this reason, we consider only individuals who report at least one hour of market work (excluding commuting). Only 1\% of the sample who report a positive amount of market work on the diary day indicate working less than one hour. Of this group, 57\% report zero time commuting to work. In contrast, only $8 \%$ of those reporting at least one hour of market work indicate no commuting time. Those with minimal market work time on the diary day may be doing flexible activities, such as checking email, and can be grouped with those reporting zero time on market work. The final sample consists of 15,798 observations.

Table 1 shows the average time devoted to Market Work and Commuting by individuals in our sample (Column 1), and the average time devoted to such activities by individuals in our sample who report positive time in Commuting (Column 2). We observe that individuals devote 7 hours and 45 minutes to Market Work during a working day, and 55 minutes to commuting. The sample correlation between Market Work and Commuting is 0.13 , indicating a significant positive relationship between the

${ }^{2}$ The MTUS team defines any diary having 91 or more minutes of missing time, having fewer than 7 episodes, or missing 2 or more of the four basic activities as a 'low quality' or 'bad case' diary. See http://www.timeuse.org/mtus/guide for more information about how good- and bad-quality diaries are defined. 
time devoted to Market Work and Commuting. Considering individuals who devote positive time to Commuting, we find that the time devoted to Market Work is 7 hours and 50 minutes per working day, while they devote 1 hour to Commuting. 92.70\% of the sample report a positive commute. Thus, we do not observe large differences in the time devoted to Market Work depending on whether individuals commute during the working day, or not. However, it is difficult to make any causal inferences on the relationship between commuting time and hours in the labour market from these raw figures. The following sections take into account individual observed heterogeneity to shed some light on the causal effect of commuting time on an individual's labour market behaviour.

\section{EMPIRICAL STRATEGY}

Using Commuting as an explanatory variable would produce biased estimates of the time devoted to the labour market, since commuting time is jointly determined with labour market hours. Similarly, we present an Instrumental Variable (IV) linear model in order to deal with endogeneity problems. The 2-equation model can be written as follows:

$$
\begin{aligned}
& l_{i}=\alpha_{t}+\beta_{1 t} \text { Commuting }_{i}+\beta_{2 t} X_{i}+\beta_{3 t} Z_{i}+\alpha_{t} \text { Day }_{i}+\varepsilon_{i t} \\
& \text { Commuting }_{i}=\alpha_{h}+\beta_{1 h} I V_{i}+\beta_{2 h} X_{i}+\beta_{3 h} Z_{i}+\alpha_{h} \text { Day }_{i}+\varepsilon_{i h}
\end{aligned}
$$

where $l_{i}$ is the time devoted to the labour market by individual ' $\mathrm{i}$ ', Commuting ${ }_{i}$ is the variable indicating the time devoted to commuting by individual 'i', $X_{i}$ is a vector of personal characteristics, $Z_{i}$ is a vector of household characteristics, and Day $y_{i}$ is a vector of dummy variables scaling the day of the week (Ref.: Friday). Within this framework, we regress the endogenous variable Commuting $_{i}$ on a set of excluded instruments $\left(I V_{i}\right)$ and included instruments $\left(X_{i}, Z_{i}\right.$ and $\left.D a y_{i}\right){ }^{3}$

The properties of the excluded instruments $\left(I V_{i}\right)$ used in Equation (2) are that they must be correlated with the endogenous explanatory variable (Commuting ${ }_{i}$ ), conditional on the other covariates and, secondly, they cannot be correlated with the error term in the explanatory equation (i.e., instruments cannot suffer from the same problem as the original predicting variable). Theoretical urban models essentially assume that residence

\footnotetext{
${ }^{3}$ See Wooldridge (2002) for more details about IV estimation.
} 
location is endogenous (e.g. Wales, 1978; White, 1988), whereas labour models assume that it is given (e.g. Gubits, 2004; Black et al., 2008). We thus keep residence location constant, and we suppose that residence location decisions are made before or after the current period of analysis, and that such decisions crucially depend on housing prices.

We rely on statistics on housing prices offered by the Ministry of Public Works to select the instruments for the analysis. The Ministry of Public Works has information (gathered by the Spanish Statistical Office) on mean prices of housing at the regional level, measured in $€ / \mathrm{m}^{2}$. We link the regional data offered by the Ministry of Public Works to diarists in the STUS, since diarists report region of residence at the time of the interview. Even though we follow labour models (e.g. Gubits, 2004; Black et al., 2008), it could be argued that residence location is endogenous, and that housing prices are also endogenous to labour market supply decisions. Hence, we use lagged and future regional housing prices. In this way, we use the following two instruments: mean housing prices in the term previous to the time use interview (lagged housing) and, secondly, mean housing prices in the term following the time use interview (future housing). ${ }^{4}$

Alternatively, we estimate an IV tobit model to account for censorship in reported time in the labour market. The 2-equation model can be written as follows:

$$
\begin{aligned}
& I_{i}^{*}=\alpha_{t}+\beta_{1 t} \text { Commuting }_{i}+\beta_{2 t} X_{i}+\beta_{3 t} Z_{i}+\alpha_{t} \text { Day }_{i}+\varepsilon_{i t} \\
& \text { Commuting }_{i}=\alpha_{h}+\beta_{1 h} I V_{i}+\beta_{2 h} X_{i}+\beta_{3 h} Z_{i}+\alpha_{h} \text { Day }_{i}+\varepsilon_{i h}
\end{aligned}
$$

where $l i *$ is the latent number of hours a diarist would choose to spend in the labour market. The actual observed hours, $l i$ will equal zero when $l i *$ is less than zero, and $l i$ will equal 24 when $l i *$ is more than 24 . The fact that we have limited the sample to diarists with at least one hour of Market Work means that the censorship at zero hours is not present, and we have no individuals reporting 24 hours of market work. Thus, we expect to obtain very similar results to the results obtained with equations (1) and (2).

We must now analyze whether these variables are good candidates to be instruments for Commuting. Regarding the first condition, that instruments must be correlated with the endogenous explanatory variable, in regions where housing prices are higher (e.g,

\footnotetext{
${ }^{4}$ The STUS covers the period from the fourth term of 2002 to the third term of 2003. See Table A1 in Appendix for a description of mean prices of housing in Spanish regions over the relevant period.
} 
Madrid and Barcelona in the Spanish case), people may find it easier to live in nonurban areas, ceteris paribus, to alleviate the problem of high housing prices. To the extent that economic activities are mostly concentrated in urban areas, those living in non-urban areas will probably have a longer commute than people living in urban areas. Thus, the higher the housing prices in the region, the higher the probability that the diarist lives in a non-urban area, and thus the greater the time devoted to commuting. The sample correlations between the time devoted to Market work and the instruments are 0.1447 and 0.1519 for lagged housing and future housing, respectively, showing a large positive relationship between the instruments and the time devoted to Commuting.

Regarding the second condition, that instruments cannot be correlated with the error term in the explanatory equation, since instruments are obtained from regional data, we do not expect to have a correlation between the time devoted to Market Work and the instruments. The sample correlations between the time devoted to Market work and the instruments are 0.0244 and 0.0261 for lagged housing and future housing, respectively, which confirms that the instruments are not correlated with Market Work.

Regarding the included instruments $\left(X_{i}, Z_{i}\right.$ and Day $\left._{i}\right)$, we include the variables that are common in time use studies, i.e., age (and its square), gender, university education, secondary education, living in couple (married/cohabiting), living in urban area, health status (dummy variables indicating whether the diarist reported having "very good health”, "good health” or "fair health”), household composition (log of the number of family members, the number of children under 18 , and the presence of children under 5 , between 5 and 12, and between 13 and 17), household income (dummy variables to control for the different income groups), and whether the household owns the dwelling. See Kalenkoski et al. (2005,2007), Connelly and Kimmel $(2007,2009)$, and Bloemen et al. (2010) for examples of variables used as controls in time use studies.

Additionally, we need to control for the type of occupation (e.g., Gimenez-Nadal et al., 2011), since it could be that the number of hours supplied by the individual is in fact a function of the type of work, rather than an individual choice. For instance, if the individual is opening a new restaurant, the individual would be less likely to be flexible than a regular employee in the hours of market work supplied. Also, the type of commitment required by so-called 'high-powered' jobs, such as law or medicine, may require a significant amount of up-front time in order to become established, so such individuals may also work longer hours. We control for the following occupations: 1) 
Management, business, financial 2) Finance/legal professional 3) Science/engineering professional 4) Civil and social services 5) Education professional 6) Medical professional 7) Other professional 8) Health/social care support 9) Clerical or office support 10) Security and armed forces 11) Sales and services 12) Farming or forestry 13) Construction, assembly, and 14) Self-employed non-professional. We also control for whether respondent work in the public sector, or not. ${ }^{5}$

Table 1 shows means and standard deviations of the explanatory variables. Males comprise $60 \%$ of the sample, the mean age is 40 years, $30 \%$ of respondents have university education, $2 \%$ report having "fair health", the number of children is 0.84 per respondent, $85 \%$ of the respondents own the dwelling, $60 \%$ of the respondents have a net household income between 1,000€ and 2,000€ per month, 19\% work in the public sector, and more than half of the sample work in finance/legal professions, farming or forestry, and self-employed non-professionals. We observe no statistically significant difference for these variables between all the respondents, and respondents with positive commuting time.

\section{RESULTS}

Columns (1) and (2) of Table 2 show the results of estimating GMM/IV linear and tobit models on the time devoted to Market Work, respectively. ${ }^{6}$ Once we control for endogeneity, we observe a positive association between Commuting and Market Work per working day, with this association being statistically significant at the $99 \%$ level. Thus, one hour of Commuting is associated with 35 more minutes of Market Work during the working day. We interpret this positive association as a causal impact, since GMM/IV estimation allows us to obtain estimates of Commuting free of endogeneity problems.

However, if we want to accept the results of the GMM/IV analyses, we have to check whether we must estimate using the 2SLS/IV estimator or the GMM/IV estimator, whether it is necessary and useful to use IV (the relevance of the instruments), whether

\footnotetext{
${ }^{5}$ We follow the classification included in the Multinational Time Use Study (MTUS) version of the Spanish data. See www.timeuse.org for a detailed description of the MTUS dataset.

${ }^{6}$ See Table A2 for a description of the GMM/IV first stage results.
} 
we have used the appropriate instruments (the validity of the instruments), and whether the quality of the instruments is sufficient. ${ }^{7}$

First, we apply the test to see whether the disturbance is homoskedastic or not. ${ }^{8}$ To that end, we estimate the linear model using the 2SLS/IV estimator, and apply the Pagan-Hall test of heteroskedasticity for instrumental variables estimation (e.g., Pagan and Hall, 1983). Under the null hypothesis (that the disturbance is homoskedastic), the Pagan-Hall statistic is distributed as chi-squared with degrees of freedom equal to the number of indicator variables (e.g., $\chi^{2}(45)$ ). In our case, the Pagan-Hall statistic is 944.665, with a p-value of 0.00. Thus, we have heteroskedastic disturbances, and we choose the GMM/IV 2-step estimator. The Generalized Method of Moments (GMM) introduced by Hansen (1982) makes use of the orthogonality conditions to allow for efficient estimation in the presence of heteroskedasticity of unknown form, generating efficient estimates of the coefficients, as well as consistent estimates of the standard errors.

The Hansen test is a test of over-identifying restrictions. For the efficient GMM/IV estimator, the test statistic is Hansen's J-statistic, the minimized value of the GMM/IV criterion function. The joint null hypothesis is that the instruments are valid instruments, that is to say, they are uncorrelated with the error term and, secondly, the excluded instruments are correctly excluded from the estimated equation. Under the null, the test statistic is distributed as chi-squared in the number of over-identifying restrictions (e.g., $\left.\chi^{2}(1)\right)$. A rejection casts doubt on the validity of the instruments. In our case, the Hansen's J-statistics yield a value of 2.325, and a p-value of 0.1273 , confirming that our instruments are valid at the $99 \%$ level.

The Anderson canonical correlations likelihood-ratio test, and the Cragg-Donald test are used to test whether the equation is identified. The statistic provides a measure of instrument relevance, and rejection of the null indicates that the model is identified. The null hypothesis of the tests is that the matrix of reduced form coefficients has rank of K1 , where $\mathrm{K}$ is the number of regressors. Under the null hypothesis of underidentification, the two statistics are distributed as chi-squared with degrees of

\footnotetext{
7 References to the tests applied after the GMM/IV estimation can be found in Baum et al. (2003), Cushing and McGarvey (1999), Davidson and MacKinnon (1993), Hall et al. (1996), Hayashi (2002), Hansen et al. (1996), Shea (1997), Stock and Yogo (2002), and Wooldridge (2002).

${ }^{8}$ We focus on the linear IV model, since results for the tobit IV model are indistinguishable.
} 
freedom of $(L-K+1)$, where $L$ is the number of instruments and $K$ is the number of endogenous regressors (e.g., $\left.\chi^{2}(2)\right)$. In our case, the Anderson and Cragg-Donald statistic yield a value of 358.85 , and a p-value of 0.00 , indicating that the model is identified.

We also include the Anderson-Rubin Wald test of the significance of the endogenous regressors in the structural equation being estimated, where the null hypothesis is that the coefficients of the endogenous regressors in the structural equation are jointly equal to zero. The chi-squared version of the statistic is distributed with 2 degrees of freedom (e.g., $\chi 2(2)$ ), and it yields a value of 14.88 , and a p-value of 0.0006 , rejecting the null hypothesis at the $99 \%$ level.

Finally, we report the F-stat form of the Cragg-Donald statistic, suggested by Stock and Yogo (2002) as a test for the presence of weak instruments (i.e., that the equation is only weakly identified). The value of the statistic is 180.95 , indicating that we can reject the presence of weak instruments.

Thus, we find a positive causal impact of Commuting time on the hours worked during a working day, with one hour of commuting increasing the time devoted to the labour market by 35 minutes. Throughout our analysis we have dealt with endogeneity problems. These results shed light on the relationship between commuting costs (time) and labour market behaviour during a working day, and we argue that both daily and weekly labour supply should be considered in theoretical models to provide a comprehensive view of commuter behaviour.

\section{CONCLUSIONS}

This paper analyses the causal effect of commuting time on labour supply patterns using data from the Spanish Time Use Survey 2002-03, which allows us to focus on the relationship between daily commuting and daily hours supplied to the labour market. We deal with the endogeneity of commuting time using GMM/IV models, where housing prices in the terms before and after the time of the interview are used as instruments. We show that commuting time increases daily labour supply, since one hour of commuting increases by 35 minutes the time devoted to the labour market during a working day. In doing so, we hypothesize that housing prices determine 
residence location decisions, although such decisions are exogenous following labour models (e.g. Gubits, 2004; Black et al., 2008).

A common assumption in the urban economic literature is that private costs of commuting are fully borne by the worker and do not affect the worker's productivity. However, urban efficiency wage theories allow that worker's work effort is a function of the length of the commute (Zenou, 2002; Ross and Zenou, 2008). Our results are in line with urban efficiency wage theories, in the sense that there is a significant causal impact between commuting and worker's labour supply. Furthermore, we argue that both daily and weekly labour supply should be considered in urban efficiency wage models to provide a comprehensive view of commuter behaviour.

We acknowledge that our results are limited by the fact that we cannot control for individual unobserved heterogeneity. While some authors consider that there is an involuntary relationship between workers' productivity and commuting (Koslowsky et al. 1995; Zenou, 2002), others consider that there is a voluntary relationship between workers' productivity and commuting (Ehrenberg, 1970), and thus individual unobserved heterogeneity may be a crucial factor in determining the workers' behaviour. However, Gutiérrez- i-Puigarnau and van Ommeren (2010) use panel data for Germany and find that commuting distance slightly increases daily and weekly labour supply, and that the number of workdays is not affected. Thus, our results, although limited by the structure of the data, are consistent with those of Gutiérrez- iPuigarnau and van Ommeren (2010). To the best of our knowledge, this is the first paper to adopt a time use perspective in the study of commuting costs and labour market behaviour.

\section{REFERENCES}

Aguiar, M. and E. Hurst (2007). "Measuring trends in leisure: The allocation of time over five decades,” Quarterly Journal of Economics, 122, 969-1007.

Baum, C. F., M. E. Schaffer and S. Stillman (2003). "Instrumental variables and GMM: Estimation and testing,” Stata Journal, 3, 1-31.

Black, D., N. Kolesnikova and L.J. Taylor (2008). "Why do so few women work in New York (and so many in Minneapolis)? Labor supply of married women across US Cities,” Federal Reserve Bank of St. Louis Working Paper 2007-043D. 
Bloemen, H., S. Pasqua and E. Stancanelli (2010). “An Empirical Analysis of the Time Allocation of Italian Couples: Are Italian Men Irresponsive,” Review of Economics of the Household, 8, 345-369.

Bovenberg, A.L., and L.H. Goulder (1996). “Optimal environmental taxation in the presence of other taxes: general equilibrium analysis,” American Economic Review, 86, 985-1000.

Cogan, J.F. (1981). “Fixed costs and labor supply,” Econometrica, 49, 945-963.

Connelly, R., and J. Kimmel (2007). “Determinants of Mothers' Time Choices in the United States: Caregiving, Leisure, Home Production, and Paid Work,” Journal of Human Resources, 42, 643-681. (2009). “Spousal Influences on Parents' Non-Market Time Choices,” Review of Economics of the Household, 7, 361-394.

Cushing, M. J. and M. G. McGarvey (1999). "Covariance matrix estimation,” in Generalized Methods of Moments Estimation, Matyas (ed.). Cambridge: Cambridge University Press.

Davidson, R. and M. MacKinnon (1993). Estimation and Inference in Econometrics (New York: Oxford University Press).

Ehrenberg, R.G. (1970). “Absenteeism and the overtime decision,” American Economic Review, 60, 352-357.

Gibbons, S., and S. Machin (2006). Transport and Labour Market Linkages: Empirical Evidence, Implications for Policy and Scope for Further UK Research. Commissioned for the Eddington Study.

Gimenez-Nadal, J.I., A. Molina and R. Ortega (2011). "Self-Employed Mothers and the Work-Family Conflict,” Applied Economics, forthcoming.

Gubits, D.B. (2004). “Commuting, Work Hours, and the Metropolitan Labor Supply Gradient,” Mimeo

Gutiérrez-i-Puigarnau, E., and J.N. van Ommeren (2010). "Labour supply and commuting,” Journal of Urban Economics, 68, 82-89. 
(2011). “Are workers with a long commute less productive? An empirical analysis of absenteeism,” Regional Science and Urban Economics, 41, 18.

Hall, A.R., G.D. Rudebusch and D.W. Wilcox (1996). “Judging instrument relevance in instrumental variables estimation” International Economic Review, 37, 283-298.

Hansen, L. (1982). "Large sample properties of generalized method of moments estimators,” Econometrica, 50, 1029-1054.

Hansen, L.P., J. Heaton and A. Yaron (1996). "Finite sample properties of some alternative GMM estimators,” Journal of Business and Economic Statistics, 14, 262280.

Hayashi, F. (2002). Econometrics (Princeton: Princeton University Press).

Hymel, K., (2009). “Does traffic congestion reduce employment growth?” Journal of Urban Economics, 65, 127-135.

Juster, T., and F. Stafford (1991). "The Allocation of Time: Empirical Findings, Behavioral Models, and Problems of Measurement," Journal of Economic Literature, 29, 471-522.

Kalenkoski, C., D. Ribar and L.S. Stratton (2005). "Parental Child Care in SingleParent, Cohabiting, and Married Couples Families: Time-Diary Evidence from the United Kingdom.” American Economic Review, 95, 194-198.

(2007). “The Effect of Family Structure on Parents' Child Care Time in the United States and the United Kingdom,” Review of Economics of the Household, 5, 353-384.

Koslowsky, M., A.N. Kluger and M. Reich (1995). Commuting Stress: Causes, Effects and Methods of Coping. Plenum Press, New York.

Manning, A. (2003). "The real thin theory: monopsony in modern labour markets," Labour Economics, 10, 105-131.

Mayeres, I., and S. Proost (2001). "Marginal tax reform, externalities and income distribution,” Journal of Public Economics, 79, 343-363.

Pagan, A.R. and D. Hall (1983). "Diagnostic Tests as Residual Analysis,” Econometric Reviews, 2, 159-218. 
Parry, I.W.H., and A. Bento (2001). "Revenue recycling and the welfare effects of road pricing,” Scandinavian Journal of Economics, 103, 645-671.

Robinson, J.P., and G. Godbey (1997). Time for Life: The Surprising Ways Americans Use their Time (University Park, Pennsylvania: The Pennsylvania State University Press).

Ross, S.L., and Y. Zenou (2008). “Are shirking and leisure substitutable? An empirical test of efficiency wages based on urban economics theory,” Regional Science and Urban Economics, 38, 498-517.

Shea, J. (1997). "Instrument relevance in multivariate linear models: a simple measure,” Review of Economics and Statistics, 49, 348-352.

Stock, J.H. and M. Yogo (2002). “Testing for weak instruments in linear IV regression,” NBER Technical Working Paper 284.

Wales, T.J. (1978). “Labour supply and commuting time: an empirical study,” Journal of Econometrics, 8, 215-226.

White, M.J. (1988). "Location choice and commuting behaviour in cities with decentralized employment,” Journal of Urban Economics, 24, 129-152.

Wooldridge, J.M. (2002). Econometric Analysis of Cross Section and Panel Data (The MIT Press, Cambridge, Massachusetts).

Zenou, Y. (2002). “How do firms redline workers?” Journal of Urban Economics, 52, 391-408. 
Table 1. Summary Statistics $1,2,3$

\begin{tabular}{|c|c|c|c|c|}
\hline \multirow[b]{2}{*}{ Time Use Variables (hours per day) } & \multicolumn{2}{|c|}{ All Respondents } & \multicolumn{2}{|c|}{$\begin{array}{c}\text { Respondents } \\
\text { Commuting }>0\end{array}$} \\
\hline & Mean & S.D. & Mean & S.D. \\
\hline Market Work & 7.736 & $(\overline{0.019)}$ & 7.824 & $(0.019)$ \\
\hline Commuting & 0.954 & $(0.006)$ & 1.030 & $(0.006)$ \\
\hline \multicolumn{5}{|l|}{ ExplanatoryVariables } \\
\hline Male & 59.863 & $(0.392)$ & 60.218 & $(0.408)$ \\
\hline Age & 40.372 & $(0.084)$ & 40.098 & $(0.087)$ \\
\hline University education & 31.007 & $(0.371)$ & 31.167 & $(0.387)$ \\
\hline Secondary education & 53.476 & $(0.400)$ & 53.683 & $(0.416)$ \\
\hline Living in couple & 71.207 & $(0.362)$ & 70.948 & $(0.377)$ \\
\hline Living in urban area & 57.948 & $(0.395)$ & 59.049 & $(0.409)$ \\
\hline Fair Health & 2.279 & $(0.120)$ & 2.235 & $(0.123)$ \\
\hline Good health & 14.015 & $(0.278)$ & 13.791 & $(0.288)$ \\
\hline Very good health & 54.993 & $(0.398)$ & 55.065 & $(0.414)$ \\
\hline Log family members & 1.218 & $(0.003)$ & 1.219 & $(0.003)$ \\
\hline Number of children $<18$ & 0.837 & $(0.008)$ & 0.840 & $(0.008)$ \\
\hline Youngest child 0-4 & 0.199 & $(0.003)$ & 0.201 & $(0.003)$ \\
\hline Youngest child 5-12 & 0.198 & $(0.003)$ & 0.198 & $(0.003)$ \\
\hline Youngest 13-17 & 0.118 & $(0.003)$ & 0.120 & $(0.003)$ \\
\hline Home ownership & 84.895 & $(0.286)$ & 84.895 & $(0.286)$ \\
\hline Hhld income $<500 €$ & 1.416 & $(0.095)$ & 1.237 & $(0.092)$ \\
\hline Hhld income 500-999€ & 11.286 & $(0.252)$ & 11.093 & $(0.261)$ \\
\hline Hhld income 1000-1250€ & 23.485 & $(0.339)$ & 23.508 & $(0.353)$ \\
\hline Hhld income 1250-1500€ & 22.054 & $(0.332)$ & 22.450 & $(0.348)$ \\
\hline Hhld income 1500-2000€ & 16.265 & $(0.295)$ & 16.454 & $(0.308)$ \\
\hline Hhld income 2000-2500€ & 10.267 & $(0.243)$ & 10.377 & $(0.254)$ \\
\hline Hhld income 2500-3000€ & 12.578 & $(0.266)$ & 12.436 & $(0.276)$ \\
\hline Hhld income $+3000 €$ & 2.649 & $(0.260)$ & 85.124 & $(0.296)$ \\
\hline Public sector & 18.578 & $(0.312)$ & 19.008 & $(0.328)$ \\
\hline Management, business, financial & 0.947 & $(0.077)$ & 0.914 & $(0.079)$ \\
\hline Finance/legal professional & 14.366 & $(0.281)$ & 14.033 & $(0.290)$ \\
\hline Science/engineering professional & 4.836 & $(0.172)$ & 4.829 & $(0.179)$ \\
\hline Civil and social services & 4.289 & $(0.163)$ & 4.346 & $(0.171)$ \\
\hline Education professional & 1.562 & $(0.099)$ & 1.556 & $(0.103)$ \\
\hline Medical professional & 4.176 & $(0.162)$ & 4.025 & $(0.166)$ \\
\hline Other professional & 2.855 & $(0.133)$ & 2.926 & $(0.139)$ \\
\hline Health/social care support & 2.111 & $(0.115)$ & 1.942 & $(0.115)$ \\
\hline Clerical or office support & 3.808 & $(0.153)$ & 3.895 & $(0.160)$ \\
\hline Security and armed forces & 6.222 & $(0.195)$ & 6.537 & $(0.207)$ \\
\hline Sales and services & 2.595 & $(0.127)$ & 2.655 & $(0.133)$ \\
\hline Farming or forestry & 21.329 & $(0.326)$ & 21.453 & $(0.340)$ \\
\hline Construction, assembly & 5.147 & $(0.175)$ & 4.346 & $(0.168)$ \\
\hline Self-employed non-professional & 25.757 & $(0.168)$ & 26.543 & $(0.173)$ \\
\hline Observations & & & & \\
\hline
\end{tabular}

Notes: ${ }^{1}$ Standard deviations in parentheses ${ }^{2}$ Sample consists of respondents aged 21-65 from the Spanish Time Use Survey $2002-2003^{3}$ Time devoted to time use activities is measured in hours per day. 
Table 2. GMM/IV estimates on hours per day devoted to Market Work ${ }^{1,2,3,4,5}$

\begin{tabular}{|c|c|c|}
\hline Market Work (Hours per day) & Linear Gmm/IV & Tobit GMM/IV \\
\hline Commuting time & $\begin{array}{c}0.578^{* * *} \\
(0.17)\end{array}$ & $\begin{array}{c}0.596^{* * *} \\
(0.17)\end{array}$ \\
\hline Male & $\begin{array}{c}1.256^{* * * *} \\
(0.05)\end{array}$ & $\begin{array}{c}1.254^{* * *} \\
(0.05)\end{array}$ \\
\hline Age & $\begin{array}{c}0.056^{* * *} \\
(0.02)\end{array}$ & $\begin{array}{c}0.055^{* * * *} \\
(0.02)\end{array}$ \\
\hline Age squared & $\begin{array}{c}-0.068^{* * *} \\
(0.02)\end{array}$ & $\begin{array}{c}-0.067^{* * *} \\
(0.02)\end{array}$ \\
\hline University education & $\begin{array}{l}-0.101 \\
(0.07)\end{array}$ & $\begin{array}{l}-0.110 \\
(0.07)\end{array}$ \\
\hline Secondary education & $\begin{array}{l}-0.080 \\
(0.06)\end{array}$ & $\begin{array}{l}-0.083 \\
(0.06)\end{array}$ \\
\hline Living in couple & $\begin{array}{c}-0.106^{* *} \\
(0.05)\end{array}$ & $\begin{array}{c}-0.105^{*} \\
(0.05)\end{array}$ \\
\hline Living in urban area & $\begin{array}{c}-0.171^{* * *} \\
(0.05)\end{array}$ & $\begin{array}{c}-0.174^{* * *} \\
(0.05)\end{array}$ \\
\hline Fair Health & $\begin{array}{r}-0.033 \\
(0.14)\end{array}$ & $\begin{array}{r}-0.036 \\
(0.15)\end{array}$ \\
\hline Good health & $\begin{array}{l}-0.042 \\
(0.06)\end{array}$ & $\begin{array}{l}-0.040 \\
(0.06)\end{array}$ \\
\hline Very good health & $\begin{array}{l}-0.010 \\
(0.04)\end{array}$ & $\begin{array}{l}-0.007 \\
(0.04)\end{array}$ \\
\hline Log family members & $\begin{array}{l}-0.040 \\
(0.06)\end{array}$ & $\begin{array}{l}-0.045 \\
(0.06)\end{array}$ \\
\hline Number of children $<18$ & $\begin{array}{l}0.042 \\
(0.04)\end{array}$ & $\begin{array}{l}0.047 \\
(0.04)\end{array}$ \\
\hline Youngest child 0-4 & $\begin{array}{c}-0.190 * * \\
(0.09)\end{array}$ & $\begin{array}{c}-0.199 * * \\
(0.09)\end{array}$ \\
\hline Youngest child 5-12 & $\begin{array}{c}-0.169 * * \\
(0.08)\end{array}$ & $\begin{array}{c}-0.172 * * \\
(0.08)\end{array}$ \\
\hline Youngest 13-17 & $\begin{array}{l}-0.026 \\
(0.08)\end{array}$ & $\begin{array}{l}-0.033 \\
(0.08)\end{array}$ \\
\hline Home ownership & $\begin{array}{l}-0.054 \\
(0.05)\end{array}$ & $\begin{array}{l}-0.053 \\
(0.06)\end{array}$ \\
\hline Public sector & $\begin{array}{c}-0.577^{* * *} \\
(0.06)\end{array}$ & $\begin{array}{c}-0.572 * * * \\
(0.06)\end{array}$ \\
\hline Constant & $\begin{array}{c}5.509 * * * \\
(0.36)\end{array}$ & $\begin{array}{c}5.484^{* * *} \\
(0.36)\end{array}$ \\
\hline $\begin{array}{l}\text { R-squared } \\
\text { Observations }\end{array}$ & $\begin{array}{c}0.152 \\
15,798\end{array}$ & $\begin{array}{c}- \\
15,798\end{array}$ \\
\hline
\end{tabular}

Notes: ${ }^{1}$ Robust standard errors in parentheses ${ }^{2}$ Sample consists of respondents aged 21-65 from the Spanish Time Use Survey 2002-2003 ${ }^{3}$ Time devoted to time use activities is measured in hours per day ${ }^{4}$ We include dummy variables to control for day of the week (Ref.: Saturday), occupation (Ref.: Self-employed non-professional) and net-monthly household income (Ref.: Hhld income $+3000 €){ }^{5}{ }^{*} p<.10 * * p<.05$ $* * * p<.01$ 


\section{APPENDIX}

Table A1. Housing prices by Spanish region (in Spanish)

\begin{tabular}{|c|c|c|c|c|c|c|}
\hline \multirow{3}{*}{ Regional housing prices } & \multirow{2}{*}{\multicolumn{2}{|c|}{$\begin{array}{c}2002 \\
\text { Term }\end{array}$}} & \multicolumn{4}{|c|}{2003} \\
\hline & & & \multicolumn{4}{|c|}{ Term } \\
\hline & $3^{\text {rd }}$ & $4^{\text {th }}$ & $1^{\text {st }}$ & $2^{\text {nd }}$ & $3^{\text {rd }}$ & $4^{\text {th }}$ \\
\hline Andalucía & 926.5 & 932.1 & 983.6 & 1037.8 & 1090.7 & 1121.3 \\
\hline Aragón & 1084.5 & 1130.8 & 1117.4 & 1186.1 & 1199.5 & 1256.3 \\
\hline Asturias (Principado de) & 1058.1 & 1102.3 & 1116.5 & 1133.6 & 1167.8 & 1227.6 \\
\hline Baleares & 1468.7 & 1508.4 & 1531.1 & 1567 & 1618 & 1631.2 \\
\hline Canarias & 1184.6 & 1209 & 1241 & 1268.5 & 1311.3 & 1329.6 \\
\hline Cantabria & 1245.1 & 1287.3 & 1308.4 & 1324.6 & 1387.9 & 1435 \\
\hline Castilla y León & 959.7 & 962.2 & 970.8 & 1001.5 & 1040.8 & 1053.1 \\
\hline Castilla la Mancha & 778.1 & 791.1 & 820.6 & 857.2 & 889.1 & 929.2 \\
\hline Cataluña & 1363.9 & 1410.2 & 1456.5 & 1520.1 & 1562.6 & 1632 \\
\hline Comunidad Valenciana & 953 & 975.9 & 1011 & 1054.2 & 1085.2 & 1112.2 \\
\hline Extremadura & 608 & 611.3 & 627.2 & 651.5 & 674.9 & 695.8 \\
\hline Galicia & 873.9 & 886.5 & 898 & 910.5 & 952.9 & 987.2 \\
\hline Madrid & 1727.5 & 1868.8 & 1936.9 & 2018 & 2122.7 & 2185.5 \\
\hline Región de Murcia & 801 & 837 & 848.1 & 878 & 945 & 987.2 \\
\hline Comunidad Foral de Navarra & 1232.8 & 1255.7 & 1258.8 & 1310.9 & 1341.5 & 1343 \\
\hline País Vasco & 1906.8 & 1948.3 & 2026.6 & 2082.8 & 2102.4 & 2107.2 \\
\hline La Rioja & 1044.4 & 1079.3 & 1131.1 & 1174.4 & 1142.2 & 1192.6 \\
\hline Spain & 1142.7 & 1164.6 & 1230.3 & 1309.6 & 1344.9 & 1380.3 \\
\hline
\end{tabular}




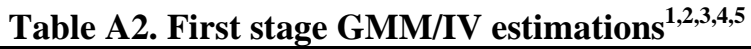

\begin{tabular}{|c|c|c|}
\hline Commuting (hours per day) & Linear Gmm/IV & Tobit GMM/IV \\
\hline Lagged housing & $\begin{array}{c}-0.002 * * * \\
(0.000)\end{array}$ & $\begin{array}{c}-0.002 * * * \\
(0.000)\end{array}$ \\
\hline Future housing & $\begin{array}{c}0.002 * * * \\
(0.000)\end{array}$ & $\begin{array}{c}0.002^{* * *} \\
(0.000)\end{array}$ \\
\hline Male & $\begin{array}{c}0.112 * * * \\
(0.013)\end{array}$ & $\begin{array}{c}0.112 * * * \\
(0.013)\end{array}$ \\
\hline Age & $\begin{array}{c}0.001 \\
(0.004)\end{array}$ & $\begin{array}{c}0.001 \\
(0.004)\end{array}$ \\
\hline Age squared & $\begin{array}{l}-0.006 \\
(0.005)\end{array}$ & $\begin{array}{l}-0.006 \\
(0.005)\end{array}$ \\
\hline University education & $\begin{array}{c}0.014 \\
(0.022)\end{array}$ & $\begin{array}{c}0.014 \\
(0.022)\end{array}$ \\
\hline Secondary education & $\begin{array}{l}-0.028^{*} \\
(0.017)\end{array}$ & $\begin{array}{l}-0.028^{*} \\
(0.017)\end{array}$ \\
\hline Living in couple & $\begin{array}{l}-0.005 \\
(0.015)\end{array}$ & $\begin{array}{l}-0.005 \\
(0.015)\end{array}$ \\
\hline Living in urban area & $\begin{array}{c}0.127 * * * \\
(0.012)\end{array}$ & $\begin{array}{c}0.127 * * * \\
(0.012)\end{array}$ \\
\hline Fair Health & $\begin{array}{c}0.020 \\
(0.037)\end{array}$ & $\begin{array}{c}0.019 \\
(0.037)\end{array}$ \\
\hline Good health & $\begin{array}{c}0.023 \\
(0.019)\end{array}$ & $\begin{array}{c}0.023 \\
(0.019)\end{array}$ \\
\hline Very good health & $\begin{array}{c}0.014 \\
(0.013)\end{array}$ & $\begin{array}{c}0.014 \\
(0.013)\end{array}$ \\
\hline Log family members & $\begin{array}{l}0.044^{* *} \\
(0.018)\end{array}$ & $\begin{array}{l}0.044^{* *} \\
(0.018)\end{array}$ \\
\hline Number of children $<18$ & $\begin{array}{l}-0.025^{*} \\
(0.013)\end{array}$ & $\begin{array}{l}-0.025^{*} \\
(0.013)\end{array}$ \\
\hline Youngest child 0-4 & $\begin{array}{c}-0.059 * * \\
(0.029)\end{array}$ & $\begin{array}{c}-0.058^{* *} \\
(0.029)\end{array}$ \\
\hline Youngest child 5-12 & $\begin{array}{l}-0.013 \\
(0.026)\end{array}$ & $\begin{array}{l}-0.013 \\
(0.026)\end{array}$ \\
\hline Youngest 13-17 & $\begin{array}{c}0.014 \\
(0.023)\end{array}$ & $\begin{array}{c}0.014 \\
(0.023)\end{array}$ \\
\hline Home ownership & $\begin{array}{c}0.012 \\
(0.016)\end{array}$ & $\begin{array}{c}0.012 \\
(0.016)\end{array}$ \\
\hline Public sector & $\begin{array}{c}-0.054^{* * *} \\
(0.017)\end{array}$ & $\begin{array}{c}-0.054^{* * *} \\
(0.017)\end{array}$ \\
\hline Constant & $\begin{array}{c}0.370 * * * \\
(0.102)\end{array}$ & $\begin{array}{c}0.372 * * * \\
(0.102)\end{array}$ \\
\hline $\begin{array}{l}\text { R-squared } \\
\text { Observations }\end{array}$ & $\begin{array}{c}0.717 \\
15,798 \\
\end{array}$ & $\begin{array}{c}- \\
15,798 \\
\end{array}$ \\
\hline
\end{tabular}

Notes: ${ }^{1}$ Robust standard errors in parentheses ${ }^{2}$ Sample consists of respondents aged 21-65 from the Spanish Time Use Survey 2002-2003 ${ }^{3}$ Time devoted to time use activities is measured in hours per day ${ }^{4}$ We include dummy variables to control for day of the week (Ref.: Saturday), occupation (Ref.: Self-employed non-professional) and net-monthly household income (Ref.: Hhld income $+3000 €)^{5 * p}<.10 * * p<.05 * * * p<.01$. 